\title{
Seismic Stratigraphy and Reservoir Characterization of 'E' Field Sediments: Inferences from South-Eastern Late Miocene - Pliocene Records, Offshore Niger Delta
}

\author{
Matthew O. Akpan ${ }^{1} \quad$ Paul. A. Udofia ${ }^{2}$ Thomas A. Harry Monday U. Udoh ${ }^{3}$ Athanasius G. Uboh ${ }^{4}$ \\ 1.Department of Geology, University of Port Harcourt, Nigeria \\ 2.Department of Geosciences, Akwa Ibom State University, Nigeria \\ 3.Pioneer Alfa Petroleum Services Ltd., Benin City, Nigeria \\ 4.Seven Energy Ltd., Uyo, Nigeria
}

\begin{abstract}
Studies of Late Miocene - Pliocene continental shelf and slopes sediments on the south-eastern continental margin, Niger Delta (a broad region from the shelf - slope break extending to the ultra-deep waters: $>1500 \mathrm{~m}$ ), have revealed markedly different responses to sea level fluctuations. Significant features of the stratigraphy include siliciclastic-dominated facies consisting principally of one or more of the following genetic types: deltaic distributary mouth bars, channel and shoreface sands, barrier beach, shelf and offshore turbidites. These sands are Late Miocene - Early Pliocene in age and were deposited in deep water settings on the slope of the ' $\mathrm{Y}$ ' field by a range of depositional processes that include slumps, debris flows and turbidity currents. Most of these sands could be interpreted to relate to periods of base level fall, if not Global Eustatic lowstands. Working within a sequence stratigraphic framework, eight (8) sequences have been delineated on the basis of reflection termination patterns. The major sequences were related to sea level fall during which the shelf was exposed to erosion. A cross section of the stratigraphic correlation drawn showed that the horizons are laterally continuous. However, pinch-out channel sands and lenticular sandbodies are evident. The recognition of depositional surfaces on the stratigraphic cross-sections allows subdivision of the stratigraphy into systems tracts: HST, FSST, TST and LST. On the seismic package, three (3) main seismic surfaces with distinct chronostratigraphic expressions are evident. They include non-marine, marine and fault plane surfaces. In addition, clinoform strata in the basin-margin setting of this field have relatively flat topsets and sloping clinoforms. On the shelf settings, a composite surface exists consisting of the merged sequence boundary, otherwise marked and interpreted as 4.2 Ma sequence boundary, transgressive surface (TS) and maximum flooding surface (MFS), unless separated by an incised valley fill (IVF). In the ' $\mathrm{Y}$ ' field, failure, slumping and re-sedimentation processes that cause base-of-slope thickening in response to gravity and geotropic flows modify the slope. Furthermore, within the same basinal setting, affected by the same sea level rise, the facies boundaries are diachronous.
\end{abstract}

Keywords: Seismic stratigraphy, Petrophysics, Sea level change, South-eastern, Miocene - Pliocene Sedimentation, Offshore Niger Delta

DOI: $10.7176 / \mathrm{JNSR} / 11-14-04$

Publication date:July $31^{\text {st }} 2020$

\section{Introduction}

The ' $Y$ ' field strata occupy a broad section in the Offshore Depobelt - Niger Delta, from the continental shelf to slope break extending to the ultra deep waters. Here, facies models of fluvial/alluvial fans, deltas and coastal barriers, tidal and wave-dominated shelf sands and turbidities were interpreted. More studies have been applied in this work based on modifications of the basic sequence "model"; for example, Rotimi, 2010., Veeken, 2007. Shanmugan, 2003., Brown, 2004., SEPM, 2005., Catuneanu, 2006., Reading, 2001., Leeder, 2001., Posamentier and Allen, 1993., Embry, 2009., Adaeze et al. 2012., Emery and Myers, 1996., Reijers, 1996., Reijers et al. 1997 and Armentrout et al. 1993, Harry, 2017; Harry, 2018

In this field, great potentials exist for clastic reservoir rocks in deep marine fans, a relatively under-explored target occurring at the base of the delta slope. The application of well log- and seismic-sequence stratigraphic analyses has helped immensely in providing methods of analyzing gross facies distribution and their relation to structure. This approach has also helped to map and identify porosity distribution, lateral variations in permeability and the presence of internal impermeable barriers, such as shale lenses; for understanding of sand-body genesis (how sands are deposited) and delineation of the spatial distribution of pore-space and barriers, in order to predict performance.

The Mio-Pliocene channels of the study area are thought to have gradually evolved into slope canyon systems that were backfilled with 'nested' sandstone units and eventually covered with fine-grained clastics during Qua Iboe time. In addition, the ' $\mathrm{Y}$ ' field sandstones are considered to have been among those over-pressured reservoirs encountered by the upwardly migrating oil entrained in the evaporative-fractionated gas phase. Consequently, medium to high API gravity oil ex-solved in these sandstones and most of the remaining gas migrated farther up 
section into shallower Benin Formation sands. The nine (9) oil wells used in this study are located in the deep Offshore Depobelt, South-eastern Niger Delta Sedimentary Basin and lay within the Concession of ELF Petroleum Unlimited (Figure 1). The ' $\mathrm{Y}$ ' field measures $22.5 \mathrm{~km} \mathrm{x} 44 \mathrm{~km}$, covering an area of approximately $990 \mathrm{~km}^{2}$. It lies between Latitudes $2^{0}$ and $4^{0} \mathrm{~N}$ and Longitudes $6^{\circ}$ and $8^{0} \mathrm{E}$. The dip section of the Niger Delta and location map are shown in Figures 2 and 3, respectively. Some wells in this field are closely spaced.

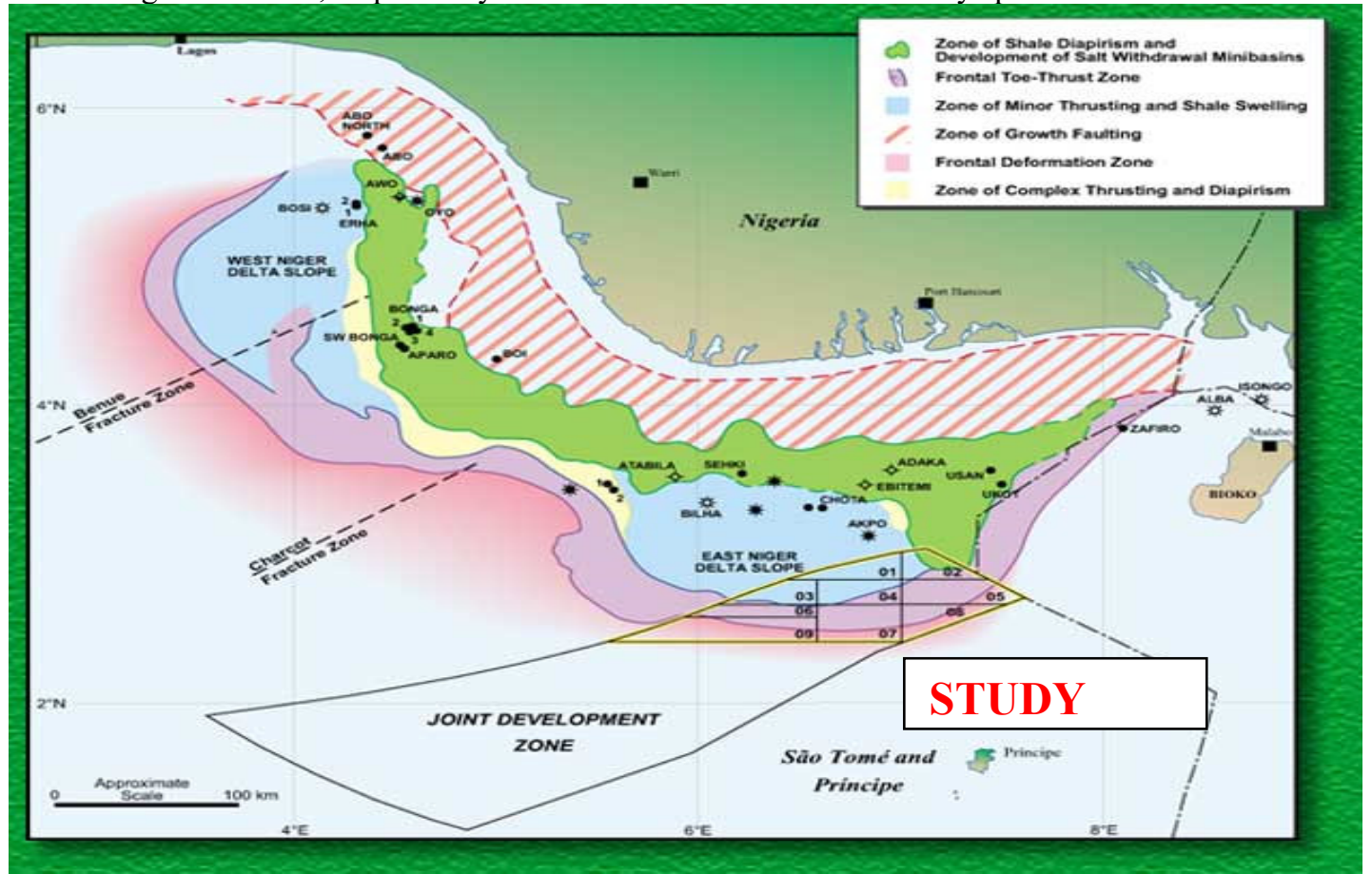

Fig. 1: Field location map, with an area of about $990.0 \mathrm{~km}^{2}$, in the Offshore, Niger Delta.

\section{Methodology and Materials}

\subsection{Data acquisition and methods}

Seismic data provided for this study by ELF PETROLEUM (NIGERIA) UNLIMITED include a high quality seismic section (Dip-and Strike-Oriented lines, NW-SE) covering nine (9) wells in the field, and is scaled 1:50000 or $10 \mathrm{~cm} / 1$ second. Identification of reflectors geologically was initially based on correlation with well log data. The Base Map is scaled 1:200000 or $1 \mathrm{~cm} / 2 \mathrm{~km}$ with closely spaced lines (Figure 4).

In this study, the reference well logs arbitrarily designated or tagged $\mathrm{W}_{\mathrm{Al}}, \mathrm{W}_{\mathrm{A}}, \mathrm{W}_{\mathrm{B}}, \mathrm{W}_{\mathrm{C}}, \mathrm{W}_{\mathrm{D}}, \mathrm{W}_{\mathrm{E}}, \mathrm{W}_{\mathrm{F}}, \mathrm{W}_{\mathrm{G}}$ and $\mathrm{W}_{\mathrm{H}}$ were evaluated and interpreted. The Dip-/strike-oriented lines 4384/1942, 4408/2194 and 4412/2558 pass through deep wells $W_{D}, W_{E}, W_{F}$, respectively. Time - Depth curves covering five (5) reference wells: $W_{A}, W_{B}$, $\mathrm{W}_{\mathrm{C}}, \mathrm{W}_{\mathrm{D}}$ and $\mathrm{W}_{\mathrm{F}}$ were produced using a Dip interval velocity survey listing carried out on the wells. The reference well $\left(\mathrm{W}_{\mathrm{D}}\right)$ has reached a total depth of $2925 \mathrm{~m}(9600 \mathrm{ft})$, becoming the deepest drilled well in the field.

Well logs data provided for this study include Spontaneous Potential (SP) and Gamma Ray (GR) Logs, Porosity logs which are: Neutron log (NPHI), Bulk Density Log (RHOB) and Sonic Log (Acoustic Velocity Log) (DT). Others include Resistivity logs (Deep Induction log (ILD), Deep Laterology (LLD), Shallow Laterology (LLS), Short Normal Induction $\log (\mathrm{SN})$. The well $\operatorname{logs}$ are scaled $1 / 10000$ or $10 \mathrm{~cm}=1$ second. The GrammaRay (GR) log was used to differentiate between argillaceous and non-argillaceous rocks, the former being more radioactive. The GR $\log$ indicates the natural radioactivity of the formations. The neutron $\log$ was used in combination with other porosity logs for lithology and shaly-sand interpretation. The combination of bulk density $\log$ with the Neutron log helps determine gas-oil contact, distinguish between oil/gas, and locate flooding surfaces and reservoir boundaries for correlations.

The biostratigraphic/paleobathymetric reports of reference wells: $\mathrm{W}_{\mathrm{C}}$ and $\mathrm{W}_{\mathrm{F}}$ were available for mapping and interpreting the first appearance or inception (FAD) and the last appearance or extinction (LAD) of a fossil species in the rock record and to establish useful markers for biostratigraphic correlation. The shifts in the water mass and circulation patterns associated with eustatic variations had profound effects on the foraminiferal distribution patterns. All of these inter-dependent factors are reflected in the biostratigraphy of the area. Biofacies analyses were used in conjunction with facies interpretations derived from seismic and well logs studies. 


\section{Results and discussion}

\subsection{Continental Shelf Settings : Sedimentology and stratigraphy}

Shelf setting encompasses coastal and neritic environments out to the limit of a physiographic shelf-edge. The facies and log patterns of the sequence boundaries on the ' $\mathrm{Y}$ '-offshore shelf vary according to the location of the section with respect to the lowstand shoreline, depositional topography, type and energy of the coastal sediment transport processes (based on Allen, 1997 findings). In the study site, two major types of sequence boundary [SB] patterns, namely landward unconformable sequence boundary and seaward conformable sequence boundary of the lowstand shoreline have been delineated and interpreted.

On the distal shelf, the sequence boundary and transgressive surface merge unless separated by incised valley fill. Since the TST is thin, as observed in Well F: $1,800 \mathrm{~m}$ at 1.675 seconds, the maximum flooding surface [MFS] is so close to the sequence boundary - SB 4.2 Ma, that it cannot be separately interpreted (Refer to seismic expressions of shelf facies in Figure 5). Here, a composite surface exists, consisting of a merged sequence boundary (SB 4.2Ma), a transgressive surface (TS) and a maximum flooding surface (MFS). In the proximal shelf settings, lowstand fluvial incised valleys erode highstand coastal plain or littoral deposits. Here, a sequence boundary (SB) occurs within a sand-prone interval between the upward thickening and coarsening HST and the sandstone channel-fill lowstand section.

On the shelf section located seaward of the sub-aerially exposed shelf unconformity (SU), the sequence boundary [SB] forms a correlative conformity recording continuous sedimentation during lowstand time (e.g., Allen, 1997).

In this study, the 4.2Ma Sequence Boundary (SB 4.2Ma) correlates with bases of a spiky, back-stepping and flat-based sandstone associated with bathyal bio-faces - interpreted as a bathyal slope-front fan and basin-floor fan of gravity flow deposits, respectively. There is a significant amount of fluvial incision, as observed and interpreted from seismic events in the study area. The occurrence of a truncation surface is a very good indicator of a type-1 4.2 Ma sequence boundary. This sequence boundary is marked by entrenched fluvial channels cut into the underlying strata in response to a relative fall in sea level.

Stratal patterns of the basin-floor fans (BFF's) and slope fans commonly exhibit mounding form with bidirectional downlap above the 4.2 Ma sequence boundary and are marked by a high amplitude reflection at the boundary. The interpreted basin floor fans are restricted to the mouth of the submarine canyon. They exhibit abrupt onlap pinch-out at the base of the pene-contemporaneous slope. The high amplitude upper reflection surface indicates strong shale-over-sand contact. The upper surface of the basin floor fan on which slope fans down-lap is sharp, reflecting the possibility of some bottom-current erosion before deposition of the overlying slope fans. On seismic reflection profile, the $5.5 \mathrm{Ma}$ sequence boundary correlates with the marine onlap [unconformity] surface or upper boundary of the submarine canyon fill facies. This disconformity, according to Bruso and Wallace, 2004, underwent further submarine erosion in the Mio-Pliocene time and became a major upper Neogene unconformity surface.

The interpreted 4.1 Ma High Frequency Sequence Boundary (HFSB/TSF 4.1 Ma) is marked by a welldeveloped continuous reflection separating slope-fans and prograding complex [PGC] - interpreted as a condensed section [CS] marking a sequence boundary. Shingled turbidites [ST] in a basinal position occur in the prograding complex [PGC] below the HFSB 4.1Ma. This high frequency sequence boundary (HFSB), according to Mitchum and Van Wagoner, 1991, represents high frequency [fourth-order] basin floor fans that developed during minor rapid sea level oscillations during the overall development of the third-order prograding complex. The prograding complexes [PGC] above the HFSB 4.1 Ma are thicker - indicating a period of basin shallowing. Shingled turbidites' configurations commonly indicate shallow-water progradational units. These sands require structural trapping mechanisms for hydrocarbon accumulation because of poor up-dip stratigraphic seals (e.g., Mitchum and Wagoner, 1991).

\subsection{Slope and Basin Settings: Sedimentology and seismic stratigraphy}

Based on the seismic events of the study site, the continental slope, or more precisely the slope break, marks a fundamental division between shallow shelf and the deep marine environment. Here, sediments channel down submarine canyon and much of the slope becomes starved. The clinoform strata in the basin-margin setting in this field have relatively flat topsets and sloping clinoforms. Failure, slumping and re-sedimentation processes that cause base-of-slope thickening in response to gravity and geotropic flows, for example - Well F, modify the slope. The prograding clinoform patterns formed by superposed sigmoidal [S-shaped] reflections were marked and interpreted as strata with thin, gently dipping upper and lower segments and thicker, more steeply dipping segments. This suggests that accommodation was increasing during deposition of the prograding strata. 


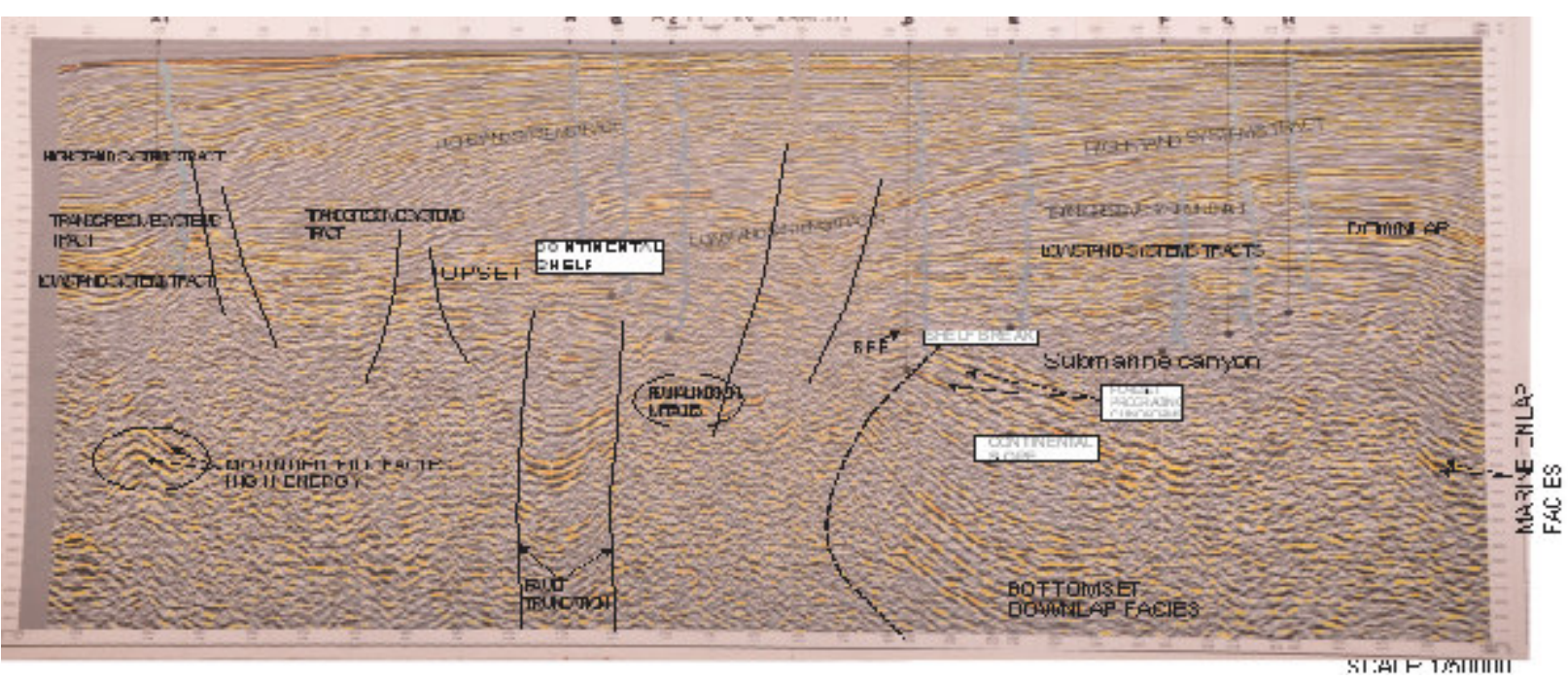

Fig. 2: Seismic facies analysis of e-field, deep offshore depobelt, niger delta sedimentarybasin (Elf Petroleum (Nigeria) 2006)

Results, based on observations of this study, are that the maximum flooding surface [MFS] coincides with the highest GR shale peaks at the base of regressive sections and can be located within precision on the logs. Unlike sequence boundaries, the timing of condensed sections - MFS 3.4 Ma; MFS 4.0Ma; MFS 5.0 Ma and MFS $5.8 \mathrm{Ma}$, is a function of both relative sea level and the rate of sediment supply. Within the same area of study and depending on the local rates of sediment accumulation, the timing of the condensed sections varies. The MFS's are continuous over wide areas and can be correlated regionally on well logs. For this reason, the MFS's generally form efficient regional hydrocarbon seals.

In more proximal shelf settings, the rates of sediment accumulation remain relatively high and a condensed section does not form. In these zones, coastal or neritic mudstones overly coastal plain or littoral deposits, representing the MFS. The maximum flooding surface [MFS] identified in Well H (i.e., at a depth of $1100 \mathrm{~m}$, 1.125 seconds), correlates with high value on gamma-ray logs and seismically defined down-lap surface of the Lowstand Prograding Wedge [LPW] - interpreted as condensed section candidate.

\subsection{Petrophysical analysis}

The relevant wire-line log signatures were employed to identify hydrocarbon-bearing reservoirs and compute reservoir petrophysical parameters like porosity, water saturation, net reservoir thickness, gross reservoir thickness and the ratio of net to gross thickness. In addition, fluid contacts were delineated. These logs include gamma ray $\log$, volume of shale log, density and neutron log, resistivity and water saturation log.

\subsection{Net - to - Gross (NTG)}

The gross reservoir thickness, $\mathrm{H}$, of the ' $\mathrm{Y}$ ' Wells was determined by looking at tops and bases of the reservoir sands across the wells. The net thickness, which is the thickness of the reservoir, was determined by defining basis for non-reservoir and reservoir sands using the gamma ray log. This was carried out by drawing a shale baseline and sand baseline on the gamma ray $\log$. The thickness of the shale, $h_{\text {shale, }}$ within the reservoir sands were obtained and therefore, subtracted from the gross reservoir thickness. Hence, Net reservoir thickness, $h=H-h_{\text {shale, }}$ and $\mathrm{Net} / \mathrm{Gross}=\mathrm{h} / \mathrm{H}$, were obtained for all the reservoirs in the field. Based on the qualitative and quantitative interpretations, nine (9) reservoirs were labeled E-R, E-R $2, E-R_{3}, E-R_{4}, E-R_{5}, E-R_{6}, E-R_{7}, E-R_{7}, E-R_{8}$ and E-R9 for ease of identification and mapping. The computed petrophysical analyses of ' $\mathrm{Y}$ ' field reservoirs are well shown in table 1 below. 
Table 1: Petrophysical analysis of ' $Y$ ' field reservoirs

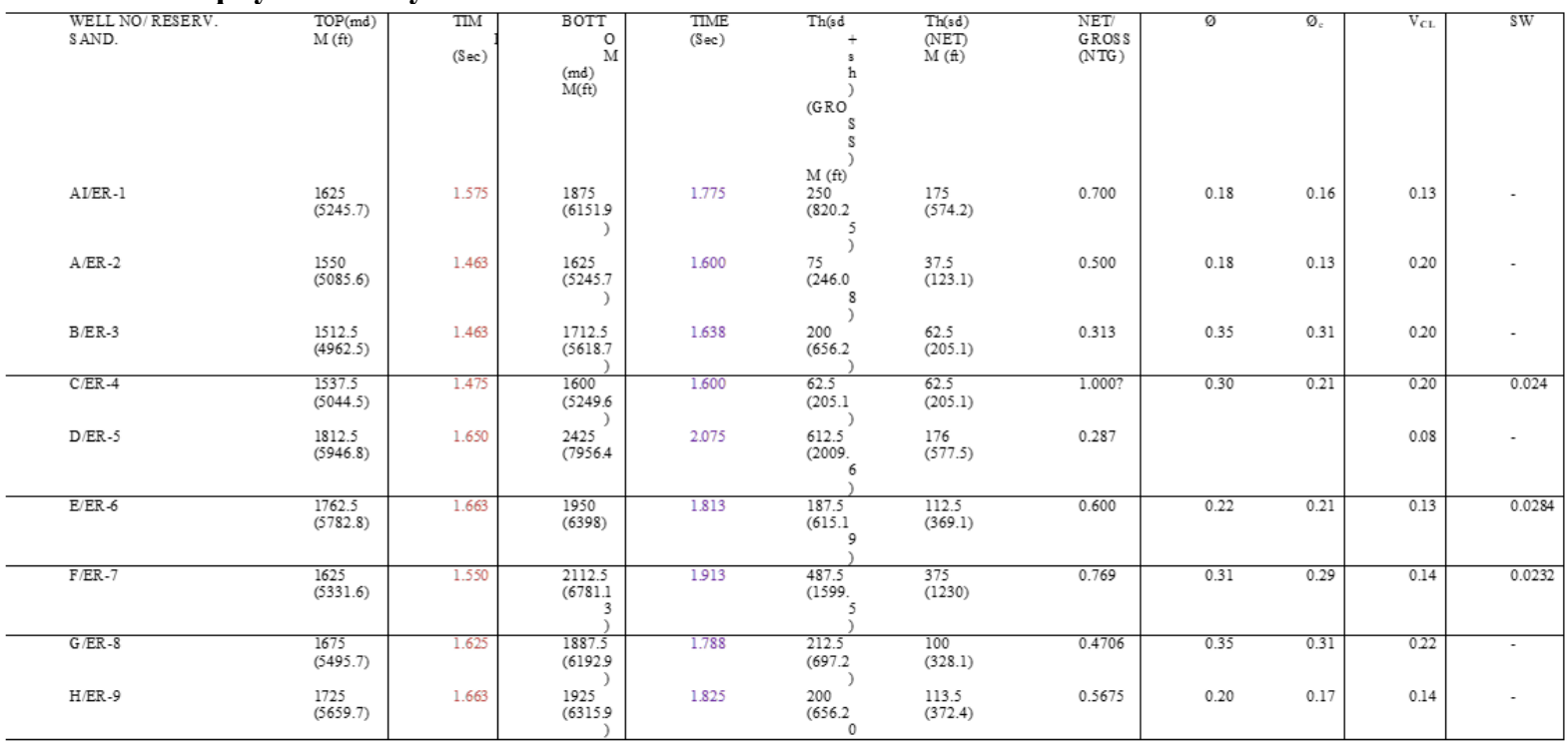

Porosity estimates in these reservoirs vary from $0.18-0.35$ and the net thicknesses of the reservoir sand range from $37.5 \mathrm{~m}(123.1 \mathrm{ft})$ to $375 \mathrm{~m}(1230 \mathrm{ft})$. Average water saturation is 0.0252 , while the effective porosity values range from 0.13 to 0.31 . Porosity and permeability increased with increasing reservoir quality. These reservoir sands have been deemed quite appreciable for commercial hydrocarbon production. Subaqueous (submarine) fans in this field are relatively under-explored reservoir types that hold great promise because of the amount of sand that is present, the potential for stacking fan lobes, and the likely proximity to deep basinal rocks.

The oil-bearing formations were deposited in a deepwater setting on the slope of the ' $\mathrm{Y}$ '-field by a range of processes that include slumps, debris flows and turbidity currents and are Late Miocene to Early Pliocene in age. Further, during the late Miocene and Early Pliocene, the ' $Y$ ' field was subjected to a major marine transgression interspersed.

\section{Conclusions}

Detailed study of well logs, seismic and biostratigraphic data provided for this study shows that the ' $\mathrm{Y}$ ' field strata were deposited in the Offshore Niger Delta and within this field, the differing facies types represent a continuum of laterally adjacent high - to low - energetic depozones with characteristic hydrodynamic conditions. The depositional environments in this field point to a fluvial, deltaic, shelf, slope, and deeper basin origin and characterize the distribution of reservoir facies. The variations in lithofacies thicknesses observed could be attributed to variations in sediment supply, rate of sea level rise and fall, syn-sedimentary tectonism or error in data processing. In spite of these variations, there exists a good correlation between the wells. From this study, the reservoir quality deduced is strongly influenced by grain size.

The basin floor fans have customary porosity values (average of 0.22 ). Slope fans exhibit several depositional styles depending on the vertical gradient of the slope. This can be the reason for the range of porosity values observed in them, for example, $0.22,0.31$ and 0.35 . Despite the small data set provided for this study, sequence stratigraphy can be successfully applied on a field scale when combined with detailed facies and petrophysical analysis to produce a predictive framework for reservoir size, amalgamation and interconnectivity, and to assist in the building of geological models.

Finally, it could be assumed that the slope litho-stratigraphy in the study area, is mainly the product of variations in siliciclastic input and the mid-shelf mud deposits are the main source of enhanced slope siliciclastic flux during lower sea level stands. Furthermore, the maximum erosion of these muds occurs when they are intersected by the shoreface.

\section{References}

Adaeze, I. U; Samuel, O. O. and Iwuagwu, C. J; 2012: Petrophysical Evaluation of Uzek Well using Well Log and Core Data, Offshore Depobelt, Niger Delta, Nigeria. In: Advances in Applied Science Research, 2012, 3(5): $2966-2991$.

Allen, J. R. L; 1974: Studies in Fluviatile Sedimentation: An Exploratory Quantitative Model for the Architecture of Avulsion-controlled Alluvial Suites, Sedimentary Geology; V. 21; P. 129 - 147.

Allen, G. P; 1997: Principles of Siliciclastic Sequence Stratigraphy and Applications to Fluvial and Shelf Deposits; P. $1-58$. 
Allen, G. P; and Posamentier, H. W; 1993: Sequence Stratigraphy and Facies Model of an Incised Valley Fill: The Gironde estuary, France, Journal of Sedimentary Petrology, V. 63; P. 378 - 392.

Amajor, L. C; 1991: Aquifers in the Benin Formation (Miocene-Recent), Eastern Niger Delta. Nigerian Lithostratigraphic, Hydraulic and Water Quality. Environmental Geology and Water Science, Vol. 7(2); P. $85-111$.

Armentrout, J. M; Malecek, S. J; Fearn, L. B; 1993: Log-motif Analysis of Paleogene Depositional Systems Tracts; Central and Northern North Sea: Define by Sequence-Stratigraphic Analysis: London Geological Society, P. $1-41$.

Asquith, G; 2004: Basic Well Log Analysis. American Association of Petroleum Geologists. Methods in Exploration Series: AAPG; Tulsa, Okllahoma, No. 16, P. 12 - 135.

Avbovbo, A. A; 1978: Tertiary Lithostratigraphy of the Niger Delta: AAPG Bull; Vol. 62; P. 295 - 300.

Bamidele, O. F. and Ehinola, O. A; 2010: Fault Analysis, Stratigraphic Discontinuities and 3D Structural Modelling of TB-Field, Offshore Niger Delta.(Adapted from extended abstract and slides prepared for oral presentation at AAPG International Conference and Exhibition, Rio de Janeiro, Brazil, November 15 - 18 , 2009).

Beka, F. T. and M. N. Oti; 1995: The distal offshore Niger Delta: Frontier prospects of a mature Petroleum Province, in: Oti, M. N. and Postma, G; eds. Geology of Deltas: Rotterdam, A. A. Balkema, P. 237-241.

Brown, L. F; Jr; and Fisher, W. L; 1980: Seismic Stratigraphic Interpretation and Petroleum Exploration: Interpretation of Depositional Systems and litho-facies from Seismic Data. Special Publication No. 24; International Association of Sedimentologists.

Bouvier, J. D. C. H, Kaars-Sijpesteinjn, D. F. Kluesner, C. C. Onyejekwe, and R. C. Van Derpa; 1989: Three Dimensional Seismic Interpretation and Fault Sealing Interpretations, Nun River Field, Nigeria. AAPG Bulletin, vol. 73; No. 11, P. 1397-1414.

Brown, L. F; Jr; and Fisher, W. L; 1980: Seismic Stratigraphic Interpretation and Petroleum Exploration: Interpretation of Depositional Systems and Litho-facies from Seismic Data. Special Publication No. 24; International Association of Sedimentologists.

Brown, A. R; 2004: Interpretation of Three - Dimensional Seismic Data: AAPG; Memoir 42, SEG Investigations in Geophysics. No.9, P. 12 - 89.

Bruso, J. M. (Jr); Getz, S. L; and Wallace, R. L; 2004: Exploration and Development. Gulf of Guinea's Golden Rectangle Geology. (Adapted from the February 16, Edition of Oil and Gas Journal). Penn Well Corporation. P. $1-8$.

Catuneanu, D; 2006: Principles of Sequence Stratigraphy: Elsevier Radarweg Publishing. 29, P. O. Box 211, 1000 AE Amsterdam. P. $42-54$.

Embry, A; 2009: Practical Sequence Stratigraphy., Canada Soc. of Petroleum Geologists; P.79.

Emery, D. and Myers, K. J; 1996: Sequence Stratigraphy, Blackwell Science, Oxford.

Ekweozor, C. M; and E. M. Daukoru, 1984: Petroleum Source Bed Evaluation of the Tertiary Niger Delta: Reply: AAPG Bulletin, Vol. 68, P. $390-394$.

Evamy, B. D., J. Haremboure, P. Kamerling, W. A. Knaap, F. A. Molloy, and P. H. Rowlands, 1978: Hydrocarbon Habitat of Tertiary Niger Delta: AAPG Bulletin, V. 62, P. $1-39$.

Frankl, E. J; and E. A. Cordry, 1967: The Niger Delta Oil Province-Recent Developments Onshore and Offshore: Seventh World Petroleum Congress, Mexico City, Proceedings, V. 1B, $195-209$.

Giwa, G. O; Oyede, A. C; Okosun, E. A; 2003: Emerging Trends in the Application of Biostratigraphy to Petroleum Exploration and Production. NAPE, 2003; P. 1 - 18.

Harry, T., Bassey, C., Udofia P., Daniel, S, (2017): Baseline study of Estuarine Oceanographic Effects on Benthic foraminifera in Qua Iboe, Eastern Obolo and Uta Ewa/Opobo River Estuaries, Southeastern Nigeria. Vol. 8. 2017. 1422.

Harry, T.A, Etuk, S. E, Joseph, Okoli Austin (2018) Geomechanical evaluation of reservoirs in the coastal swamp, Niger delta region of Nigeria. 2018, 2018. 6(2): p. 8

Harry, T.A, Ushie, F.A, Agbasi, O. E (2018): Hydraulic and Geoelectric relationships of Aquifers Using Vertical Electrical Sounding (VES) in parts of Obudu, Southern Nigeria. Vol

Haq, B. U; 1991: Sequence stratigraphy, Sea-Level Change, and Significance for the Deep Sea. Spec. Publs. Int. Ass. Sediment (1993), Vol. 12, P. 3 - 39.

Jev, B. I; C. H. Kaars-Sijpesteijn, M. P. A. M. Peters, N. L. Watts, and J. T. Wilkie; 1993: Akaso field, Nigeria: Use of Integrated 3-D seismic, Fault Slicing, Clay Smearing, and Dynamic Leakage: AAPG Bulletin, V. 77; P. $1389-1404$.

Ladipo, I. O; 1992: Sequence Stratigraphic Analysis: An Example of Application to Prospect Appraisals in the North Western Niger Delta. NAPE Bull; Vol. 17, (1); P. 153 - 158.

Leeder, M. R; 2001: Sedimentology and Sedimentary Basins: From Turbulence to Tectonics; P. 258 - 529 ; Blackwell Science, Boston. 
Mitchum, R. M; Jr. and Van Wagoner, J. C; 1991: High-Frequency Sequences and their Stacking Patterns: Sequence-Stratigraphic evidence of High-frequency Eustatic Cycles, Sedimentary Geology, 70, P. 131-160.

Mitchum, R. M; J. B. Sangree, P. R. Vail and W. W. Wornardt; 1992: Recognising Sequences and Systems Tracts from Well Logs, Seismic Data, and Biostratigraphy: Examples from the Late Cenozoic of the Gulf of Northern North Sea. Marine and Petroleum Geology: Vol. 9, P. $289-301$.

Nton, M. E. and Esan, T. B; 2010: Sequence Stratigraphy of EMI Field, Offshore Eastern Niger Delta, Nigeria. In: European Journal of Scientific Research, Vol. 44 No.1 (2010), P. 115 - 130.

Oboh - Ikuenobe, F. E; Obi, C. G; and Jaramillo,C. A; 2005: Lithofacies, Palynofacies, and Sequence Stratigraphy of Paleogene Strata in Southeastern Nigeria. Elsevier Ltd; Journal of African Earth Sciences, 41 (2005); P. $79-101$.

Oomkens, E; 1974: Litho-Facies Relations in the Late Quaternary Niger Delta Complex: Sedimentology, V. 2; P. $195-222$.

Posamentier, H. W; Allen, G. P; 1993: Variability of the Sequence Stratigraphic Model: Effects of Local Basin Factors; Sedimentary Geology, Vol. 86, P. 91 - 109.

Posamentier, H. W and Erskine, R. D; 1991: Seismic Expression and Recognition Criteria of Ancient Submarine Fans. In: Seismic Facies and Sedimentary Processes of Submarine Fans and Turbidite Systems (eds. P. Weimer \& M. H. Link), P. 197-222, Spinger, Berlin.

Reading, H. G; 2001: Clastic Facies Models, a Personal Perspective. In: Bulletin of the Geological Society of Denmark; Vol. 48, P.101 - 115. Copenhagen.

Reijers, T. J. A; 1996: Selected Chapters on Geology \& Three Case Studies and Field Guides: Sedimentary Geology and Sequence Stratigraphy in Nigeria. Shell Petroleum Development Co. (Nig) Ltd; International Publication. P. $45-149$.

Reijers, T. J. A, Peters, S. W; and Nwajide, C. S; 1997: The Niger Delta Basin, in Selley, R. C; ed; African Basins - Sedimentary Basin of the World 3: Amsterdam, Elsevier Science, P. $151-172$.

Rotimi, O. J; 2010: Sequence Stratigraphy Study within a Chronostratigraphic Framework of "Ningning Field", Niger Delta. RMZ - Materials and Geo-environment, Vol. 57, No. 4, P. 475 - 500.

SEPM, 2005: SEPM Sequence Stratigraphy: Exercise in Analysis of High Frequency (2005)

Shanmugan, G; 2003: Delineation of Wireline Log Motifs, Mobil 21D Well, Edop Field, Offshore Nigeria, MPN EDOP 21D.

Shanmugan, G; 1997: Deep Water Exploration: Conceptual Models and Their Uncertainties: NAPE Bulletin, V. 12/01, P. $11-28$.

Vail, P. R; Audermard, F. Bowman, S. A., Eisner, P. N. and Perez Cruz, G; 1991: The Stratigraphic Signatures of Tectonics, Eustacy and Sedimentation - An Overview. In: Einsele et al; (Editors) Cyclic Stratigraphy, Springer Verlag, New York, P. 617 - 659.

Veeken, P. C. H; 2007: Seismic Stratigraphy, Basin Analysis and Reservoir Characterization, vol. 37; Handbook of Geophysical Exploration, Elsevier; P. 1 - 526.

Weber, K. J; 1971: Sedimentological Aspects of Oilfields in the Niger Delta. Geol. En. Mijnbouw. Vol. 50, P. 559-576.

Weber, K. J; 1982: Influence of Common Sedimentary Structures on Fluid Flow in Reservoir Models.Journal Petroleum Technology, P. $665-672$.

Weber, K. J; and Daukoru, E; 1975: Petroleum Geology of the Niger Delta. $9^{\text {th }}$ World Petrol. Congress, Tokyo Proceedings. Vol. 2; P. 205 - 222. Applied Science, London.

Whiteman, A. J; 1982: Nigeria: Its Petroleum Geology, Resources and Potentials, Vol. 11, Graham and Trotman, London, P. $110-311$. 